\title{
MODEL JOINT OPERATION DALAM PRIVATISASI PENGELOLAAN PTPN XIV PABRIK KAPAS JENEPONTO
}

\author{
Fadliah Yusman ${ }^{1}$, Muhlis Madani2, ${ }^{2}$ Handam $^{1}$ \\ ${ }^{1}$ Program Studi Ilmu Pemerintahan Fakultas Ilmu Sosial dan Ilmu Politik \\ Universitas Muhammadiyah Makassar \\ Jl Sultan Alauddin No 259 Makassar 90221 \\ Telp. 0411-866972 ext. 107. Fax. 0411-8655888 \\ fadliahyusman@yahoo.co.id handam@unismuh.ac.id \\ 2 Program Studi Ilmu Adminitrasi Negara Fakultas Ilmu Sosial dan Ilmu Politik \\ Universitas Muhammadiyah Makassar \\ Jl Sultan Alauddin No 259 Makassar 90221 \\ Telp. 0411-866972 ext. 107. Fax. 0411-8655888 \\ muhlismadani@yahoo.com
}

\section{ABSTRACT}

This study aims to determine the model of privatization of the management of Joint Operations at PT. Perkebunan Nusantara XIV Cotto factory Jenponto. The data collection was done by using field research, library research and document data searches. The data were then analyzed qualitatively. The results showed that the model of Joint Operation in the privatization of the management of PT Perkebunan Nusantara XIV Cotton factory Jeneponto to cooperate PT Supin Raya. Factors that are supporting the success of privatization is close supervision and the amount of raw material supply. Factors affecting the failure is a problem in making the agreement, the rental price of production services, late payment of rental services, limited production facilities and infrastructure.

Keywords: joint operation, privatization, cotton factory

\begin{abstract}
ABSTRAK
Penelitian ini bertujuan untuk mengetahui privatisasi pengelolaan dengan model Joint Operation pada PT. Perkebunan Nusantara XIV Pabrik Kapas. Pengumpulan data ini dilakukan dengan menggunakan teknik penelitian lapangan, penelitian kepustakaan dan penelusuran data dokumen. Data yang diperoleh selanjutnya dianalisis secara kualitatif. Hasil penelitian menunjukkan bahwa model Joint Operation dalam privatisasi pengelolaan PT Perkebunan Nusantara XIV Pabrik Kapas Jeneponto dengan bekerja sama PT Supin Raya. Faktor yang yang mendukung keberhasilan privatisasi yaitu pengawasan yang ketat dan jumlah pasokan bahan baku. Faktor yang mempengaruhi kegagalan yaitu masalah dalam pembuatan surat perjanjian, harga sewa jasa produksi, keterlambatan pembayaran sewa jasa, keterbatasan sarana dan prasarana produksi.
\end{abstract}

Kata kunci: joint operation,privatisasi, pabrik kapas 


\section{A. PENDAHULUAN}

Di Indonesia, hampir seluruh perusahaan yang dikelola negara atau BUMN tidak menunjukkan kinerja finansial yang baik. Laporan Bank Dunia tentang public sector di Indonesia tahun 1999 menunjukkan fenomena tersebut, yaitu: (1) kebanyakan BUMN menyedot anggaran pemerintah yang sebenarnya bisa dialokasikan untuk pelayanan sosial; (2) kebanyakan BUMN mengambil kredit untuk investasi yang tidak tepat; (3) kebanyakan BUMN tidak efisien dibandingkan perusahaan swasta; dan (4) diharapkan dengan perbaikan manajemen BUMN menghasilkan efisiensi. Proyeksi hasil penelitian tim PSPK BAF menunjukaan bahwa tahun 2004, 2005 dan 2006 jumlah BUMN yang kinerjanya mengalami kerugian berjumlah 70 BUMN (45\% dari 154 BUMN) dengan nilai total kerugian lebih besar daripada total keuntungan BUMN, yaitu sebesar Rp 33,376 triliun ( 2004), Rp 35,150 triliun (2005) dan Rp 37,971 triliun (2006) (Patriadi dan Purwoko, 2007:4). Hal inilah yang mendorong untuk menerapkan privatisasi pada BUMN.

Perhatian pemerintah melakukan kajian mengenai privatisasi sesungguhnya baru menjadi topik kajian kalangan para akademis maupun praktisi, secara serius yaitu pada era tahun 1990an. Dimana pada saat itu kondisi beban pembangunan dipundak pemerintah sudah mulai semakin tidak mampu menyediakan anggaran yang cukup, untuk membangun infrastruktur. Bahkan untuk sekedar pemeliharaan terhadap infrastruktur yang sudah di bangun juga kurang di perhatikan dukungan pembiayaan yang memadai. Hal itu juga semakin tidak dipungkiri aset yang sedemikian besar tersebut sudah banyak yang kurang berfungsi, hancur dan hilang.
Upaya pemerintah dalam rangka memperbaiki kinerja BUMN dilakukan antara lain melalui Privatisasi BUMN. Oleh karena itu penguasaan tanah oleh investor menjadi sangat penting karena tanah adalah obyek utama dari pengembangan itu sehingga timbul kecenderungan bahwa investor berupaya untuk menguasai tanah seluas-luasnya dengan modal yang minim, hal inilah yang kemudian memunculkan konsep baru seperti BOT (Build operate Transfer), BOO (Build operate Own), BROT (Build Rent Operate Transfer), KSO (Kerjasama operasi/Joint Operation), usaha patungan dan sebagainya, merupakan fenomena yang baru.

Perjanjian kerjasama operasi (KSO) merupakan salah satu perjanjian yang sedang diminati untuk dilakukan oleh perusahaan-perusahaan saat ini khususnya Indonesia. KSO sendiri mempunya arti perjanjian antara dua pihak atau lebih dimana masing-masing sepakat untuk melakukan suatu usaha bersama dengan menggunakan aset dan/atau hak usaha yang dimiliki dan secara bersama menanggung resiko uasaha tersebut.

Saat ini, salah satu perusahaan BUMN yang bergerak dalam bidang pengelolaan kapas PT. Perkebunan Nusantara XIV Pabrik Kapas Jeneponto terancam di non-operasikan. Disebabkan karena kurangnya bahan mentah sehingga menyebakan nilai produksi yang semakin menurun. Oleh karena itu, pihak perusahaan mengambil kebijakan untuk melakukan privatisasi pada PT. Perkebunan Nusantara XIV Pabrik Kapas Jeneponto. Kebijakan privatisasi yang diambil bagi PT. Perkebunan Nusantara XIV adalah model Joint Operation dengan PT. Supin Raya.

Kerjasama ini telah kurang lebih telah berjalan selama 3 tahun belakangan ini. Kebijakan privatisasi dalam model 
Joint Operation yang di ambil pada PTPN XIV Pabrik Kapas Jeneponto dengan PT. Supin Raya untuk mengoptimalkan produksi kapas yang mulai menurun sejak tahun 1996 sehingga mengakibatkan banyak pegawai yang dimutasi. Sehingga pada tahun 2008 mulai melakukan kerjasama Produksi (Joint Operation) dimana PT. Supin Raya selaku penyedia bahan dan di Produksi pada PTPN XIV pabrik kapas Jeneponto. Maka penelitian ini membahas tentang "Model Joint Operation dalam privatisasi pengelolaan PTPN XIV Pabrik Kapas Jeneponto".

\section{B. KONSEP PRIVATISASI}

Secara konseptual privatisasi pada dasarnya merupakan hasil kebijakan politik dimana Pemerintah mendorong melalui kebijakan-kebijakan dan program-program. Proyek bahkan industri, perencanaan, budget, kebijaksanaan dan persetujuan penanaman modal (investasi) ditangan pemerintah. Dalam Good Governance tidak lagi pemerintah, tetapi juga citizen, masyarakat dan terutama sektor usaha/swasta yang berperan dalam governace. Justru usaha pembangunan melalui koordinasi/sinergi (keselarasan kerja/interaksi) antara pemerintah, masyarakat dan swasta. Hal ini dapat dilihat sebagai bentuk pemerintah memberdayakan masyarakat terutama sektor usaha agar menjadi partner pemerintah.

Menurut pasal 1 butir 12 UU No 19. 2003 tentang BUMN yang dimaksud dengan privatisasi adalah penjualan saham persero, baik sebagian maupun seluruhnya, kepada pihak lain dalam rangka meningkatkan kinerja dan nilai perusahaan, memperbesar manfaat bagi negara dan masyarakat, serta memperluas pemilikan saham oleh masyarakat. Prawira santosa, Setyanto (2007: 13) menurutnya privatisasi adalah salah satu cara efektif memperbaiki kinerja BUMN dari faktor internal dan eksternal perusahaan tersebut, sehingga banyak perusahaan terutama BUMN melakukan privatisasi untuk memperbaiki kinerja perusahaan.

Menurut Putra dkk (2001 : 93), ada berbagai alasan perlunya dilakukan privatisasi: Pertama, alasan yang bersifat praktis, yaitu bagaimana biaya dapat dikurangi, proyek jangka pendek dapat dioptimalkan secara ekonomis, pelayanan dapat disediakan lebih hemat, sumbersumber yang terbatas dapat diganti dan beberapa kegiatan pemerintah dapat ditingkatkan. Kedua, alasan yang bersifat ideologis, yaitu karena suatu realitas politik, pegawai-pegawai pemerintah biasanya kurang efisien dan kurang ekonomis, sifat monopoli, tidak ada kemauan untuk bekerja dengan baik, ukuran pemerintah yang lebih kecil adalah yang lebih baik, pemerintah seharusnya hanya menyediakan pelayanan yang tidak bisa dilakukan swasta, mengurangi pajak, serta meningkatkan kegiatan ekonomis.

Selain faktor pembentukan privatisasi, adanya tujuan privatisasi dari sisi pembenahan internal manajemen (jasa dan organisasi) yaitu: meningkatkan efisiensi dan produktivitas, mengurangi peran negara dalam pembuatan keputusan, mendorong penetapan harga komersial, organisasi yang berorientasi pada keuntungan dan perilaku bisnis yang menguntungkan, dan meningkatkan pilihan bagi konsumen.

Dari sisi ekonomi, tujuan privatisasi yaitu: memperluas kekuatan pasar dan meningkatkan persaingan, mengurangi ukuran sektor publik dan membuka pasar baru untuk modal swasta.

Tujuan dari segi politik yaitu: mengendalikan kekuatan asosiasi/ perkumpulan bidang usaha bisnis tertentu dan memperbaiki pasar tenaga 
kerja agar lebih fleksibel, mendorong kepemilikan saham untuk individu dan karyawan serta memperluas kepemilikan kekayaan, memperoleh dukungan politik dengan memenuhi permintaan industri dan menciptakan kesempatan lebih banyak akumulasi modal spekulasi, dan meningkatkan kemandirian dan individualisme.

Adapun tujuan pelaksanaan privatisasi sebagaimana tercantum dalam Pasal 74 Undang-undang Nomor 19 Tahun 2003 Tentang Badan Usaha Milik Negara (BUMN) adalah meningkatkan kinerja dan nilai tambah perusahaan serta meningkatkan peran serta masyarakat dalam pemilikan saham Persero.

Dalam pasal KUH 1313 Perdata disebutkan perjanjian adalah suatu perbuatan dengan mana satu orang atau lebih mengikatkan dirinya terhadap satu orang lain atau lebih. Menurut Karnanto (1994:11) "kerjasama operasi adalah kerjasama antara dua perusahaan atau lebih untuk bersama-sama meyelesaikan suatu pekerjaan tertentuyang diberikan oleh pihak lain dalam jangka waktu yang relatif singkat dimana kerjasama antar pihak tersebut akan membubarkan diri bilamana pekerjaan yang ditangani bersama telah selesai dengan membagi keuntungan diantara para peserta secara proporsionil, biasanya berdasarkan pengikutsertaan dana permodalan yang semula telah disepakati bersama".

Meskipun banyak penyebutan yang digunakan dalam istilah lain dalan Joint Operation, namun semuanya samasama mengandung pengertian bahwa bentuk aliansi ini merupakan sebuah perikatan atau kerjasama antara dua badan atau lebih untuk menyelesaikan suatu proyek atau pekerjaan tanpa membentuk badan baru secara terpisah dari para peserta kerjasama. Dengan pertimbangan bahwa istilah digunakan untuk kerjasama bentuk model ini adalah Joint Operations.

Kerjasama Operasi (KSO)/ Joint Operation (JO) memiliki ciri pokok (Istianto, $2011: 36$ ) antara lain : Adanya pihak-pihak yang bekerjasama, yaitu Investor dan Pemilik Aset, Adanya perjanjian (hubungan hukum), Penggunaan asset (harta kekayaan), Adanya resiko (prestasi).

Sebutan pihak yang terkait dalam Kerjasama Operasional (KSO) adalah sebagai berikut: pemilik aset adalah pihak yang memiliki aset atau hak penyelenggaran usaha tertentu yang dipakai sebagai obyek atau sarana kerjasama operasi. Investor adalah pihak yang menyediakan dana, baik seluruh atau sebagian, untuk memungkinkan aset atau hak usaha pemilik aset diberdayakan atau dimanfaatkan dalam KSO.

Privatisasi sudah dilaksanakan pada tahun 1990-an tetapi baru mempunyai dasar hukum dalam bentuk Undang-undang pada Tahun 2003, yaitu dengan diterbitkannya Undangundang Nomor 19 Tahun 2003 Tentang Badan Usaha Milik Negara. Undangundang tersebut menjadi dasar dalam melaksanakan proses privatisasi di Indonesia. Ketentuan mengenai privatisasi dalam BUMN diatur dalam Pasal 1 butir 12 Undang-undang Nomor 19 Tahun 2003 Tentang Badan Usaha Milik Negara (BUMN) yang menyebutkan bahwa privatisasi merupakan pejualan saham Persero, baik sebagian maupun seluruhnya, kepada pihak lain dalam rangka meningkatkan kinerja dan nilai perusahaan, memperbesar manfaat bagi negara dan masyarakat, serta memperluas pemilikan saham oleh masyarakat.

Agar suatu privatisasi dapat berjalan dengan baik dan tepat tujuan, tentu harus diatur ketentuan mengenai bentuk-bentuk privatisasi yang dapat 
dilakukan oleh BUMN. Bentuk-bentuk Privatisasi tersebut sesungguhnya beraneka ragam, sehingga dalam hal ini, peraturan pemerintah yang mengatur ketentuan tersebut adalah Peraturan Pemerintah Nomor 59 Tahun 2009 Tentang Perubahan Atas Peraturan Pemerintah Nomor 33 Tahun 2005 Tentang tata cara Privatisasi Persero.

Pada penjelasannya, peraturan pemerintah ini menyebutkan bahwa privatisasi dilaksanakan berdasarkan pemikiran yang menyejajarkan peran strategis BUMN dengan kemajuan ekonomi nasional.

\section{METODE PENELITIAN}

Jenis penelitian yang digunakan adalah kualitatif dan tipe penelitian yang digunakan penulis adalah tipe deskriptif kualitatif yaitu penulis mencoba menggambarkan permasalahan yang terkait dengan Model Joint Operation Dalam privatisasi pengelolaan PT. Perkebunan Nusantara XIV Pabrik Kapas Jeneponto, menginterpretasikan serta menjelaskan data secara sistematis.

Sumber data penelitian ini terutama dijaring dari sumber data primer yaitu dengan melakukan observasi dan wawancara (interview) dengan beberapa karyawan PT. Perkebunan Nusantara XIV pabrik kapas Kabupaten Jeneponto dan PT. Supin Raya dan data sekunder adalah data yang diperoleh berdasarkan acuan dan literatur yang berhubungan dengan materi dan dokumen dari PT Perkebunan Nusantara XIV pabrik kapas Jeneponto.

Teknik pengumpulan data yang digunakan dalam penelitian oleh peneliti yaitu: observasi, wawancara dan dokumen. Teknik analisis data yang di lakukan adalah analisis kualitatif dilakukan dengan menggambarkan datadata tentang Privatisasi dalam model Joint Operation PTPN XIV pabrik kapas Jeneponto dengan PT. Supin Raya.

\section{HASIL DAN PEMBAHASAN}

PT. Perkebunan XIV (Persero) unit kapas Jeneponto adalah pengelolaan kapas berbiji. Pengusahaan budidaya tanaman kapas meliputi pembukaan dan pengolahan lahan, pembibitan, penanaman dan pemeliharaan serta melakukan kegiatan-kegiatan lain yang sehubungan dengan pengusahaan budidaya tanaman tersebut.

Produksi meliputi pemungutan hasil, pengolahan hasil tanaman sendiri maupun dari pihak lain menjadi barang setengah jadi atau barang jadi serta produk turunannya.

Perdagangan

meliputi penyelenggaraan kegiatan pemasaran berbagai macam hasil produksi serta melakukan kegiatan perdagangan lainnya yang sehubungan dengan kegiatan usaha perseroan, pengembangan usaha bidang perkebunan, agro wisata agro bisnis, dan agro forestry.

Manajemen sumber daya manusia yang baik ditujukan kepada peningkatan kontribusi yang dapat diberikan oleh para anggota dalam perusahaan ke arah tercapainya tujuan perusahaan. Untuk mampu mengemban tugas sesuai dengan tuntutan budaya perusahaan, integritas dan profesionalisme harus merupakan ciri utama insan PT. Perkebunan XIV (Persero). Secara rinci, ciri-ciri insan PT. Perkebunan XIV (Persero): Bertakwa kepada Tuhan Yang Maha Esa, Memiliki wawasan kebangsaan/tidak membedakan suku, agama, ras dan golongan, berpendidikan dan terlatih dengan baik, memiliki harga diri dan dapat dipercaya, memiliki rasa tanggung jawa yang besar, mendahulukan kepentingan perusahaan diatas kepentingan pribadi, memiliki motivasi kuat, ulet dan penuh dedikasi, kreatif dan inovatif, peka terhadap tuntutan ruang dan waktu, menghargai pendapat orang lain, memiliki rasa kesetia-kawanan yang dalam. 


\section{Visi dan Misi PT. Perkebunan Nusantara XIV (Persero)}

Visi dan misi PT. Perkebunan Nusantar XIV pabrik kapas Jeneponto diformulasikan tidak terlepas dari visi dan misi PTPN XIV adalah menjadi perusahaan agribisnis dan agroindustri di kawasan Timur Indonesia kompetitif, mandiri, dan memberdayakan ekonomi rakyat.

Rumusan misi sebagai upaya untuk mewujudkan visi dimaksud adalah sebagai berikut: (1) Menghasilkan produk uatama perkebunan berupa gula dan minyak sawit yang berdaya saing tinggi, serta produk lain seperti karet, kopra dan ternak sapi, untuk memenuhi kebutuhan pasar domestik dan/atau internasional; (2) Mengelola bisnis dengan teknologi akrab lingkungan yang memberikan kontribusi nilai kepada produk dan mendorong pembangunan berwawasan lingkungan; (3) Melalui kepemimpinan, team work, inovasi, dan SDM yang kompeten, dalam meningkatkan nilai secara terus-menerus kepada stakeholders; (4) Menempatkan sumber daya manusia sebagai pilar utama penciptaan nilai (value creation) yang mendorong perusahaan tumbuh dan berkembang bersama mitra strategis.

Maksud dan tujuan pendirian perusahaan sesuai Anggaran Dasar Perusahaan, Pasal 3, Ayat 1 adalah turut melaksanakan dan menunjang kebijaksanaan dan program Pemerintah di bidang ekonomi dan pembangunan nasional pada umumnya, khususnya sub sektor pertanian dengan berdasarkan prinsip-prinsip perseroan terbatas. Maksud dan tujuan dari perseroan ini ialah melakukan usaha-usaha di bidang perkebunan dalam arti kata yang seluasluasnya, dengan berlandaskan asas: (1) Mempertahakan dan meningkatkan sumbangan bidang perkebunan bagi pendapatan nasional, yang diperoleh dari hasil produksi dan pemasaran beberapa jenis komoditi/produk untuk keperluan ekspor dan konsumsi dalam negeri; (2) Memperluas lapangan kerja untuk meningkatkan tarap hidup petani serta karyawan pada khususnya; dan (3) Memelihara kekayaan alam, khususnya menjaga kelestarian dan meningkatkan kesuburan tanah, sumber serta tata air.

\section{Penerapan Privatisasi dalam} bentuk Joint Operation antara PT. Perkebunan Nusantara XIV Pabrik Kapas Jeneponto dan PT Supin Raya

Dalam penerapan perjanjian ini, pihak PTPN menerima dan mengolah kapas berbiji yang diberikan dari pihak PT Supin Raya. Hal pertama yang dilakukan sebelum pengolahan kapas adalah pembicaraan tentang sewa jasa pengolahan kapas berbiji per Kg. Pada pengolahan tahun 2013, harga sewa jasa pengolahan kapas berbiji milik PT Supin Raya sebesar Rp. 1030 per kilo. Namun, pengolahan kapas akan mulai dilaksanakan apabila kapas bebiji telah mencapai standar pengolahan 60 ton. Setelah kesepakatan dalam harga jasa pengolahan telah didapatkan, selanjutnya pihak PTPN XIV (Persero) Pabrik Kapas Jeneponto mengecek keadaan pabrik, apakah mesin pabrik bisa digunakan secara optimal sekaligus memperkirakan biaya operasional yang dibutuhkan selama proses pengolahan kapas.

Segala proses pengolahan mulai dari bongkar dan sortasi kapas berbiji, pemisahan serat kapas dari bijinya, biaya operasional ginnery (BBM dan tenaga kerja), sarana pendukung lainnya (plastik dan kawat), serta volume kapas berbiji yang diginning dilakukan di pabrik milik perkebunan PTPN XIV pabrik kapas Jeneponto. Setelah pengelolaan kapas selesai diolah dipabrik hasil olahan kemudian disimpan didalam gudang milik PT Perkebunan Nusantara XIV Pabrik kapas Jeneponto dan tidak dipungut biaya, serta menjaga serat kapas yang ada digudang sampai hasil 
olahan tersebut laku terjual. Adapun resiko kerugian yang tidak diinginkan berupa kebakaran yang mana tindakan diluar kemampuan manusia (force majure) menjadi beban masing-masing pihak.

\section{Infrastruktur PT Perkebunan Nusantara XIV Pabrik kapas Jeneponto}

Sebagai kebutuhan dasar fisik pengorganisasian sistem, infrastruktur diperlukan untuk jaminan sektor bisnis sebagai layanan dan fasilitas yang diperlukan agar perekonomian dapat berfungsi dengan baik khususnya pada PTPN XIV Pabrik Kapas Jeneponto. Dimana kegiatan yang dilakukan dalam proses kerjasama ini keberadaan infrastruktur yang baik sangat dibutuhkan dalam pengolahan kapas di pabrik milik PTPN XIV Pabrik Kapas Jeneponto guna mencapai tujuan bersama.

Jenis infrastruktur pada PTPN XIV Pabrik Kapas Jeneponto yaitu: jumlah mess 1 unit, rumah dinas pimpinan 1 unit, kantor unit dan kantor teknik 2 unit, mushollah 1 unit, Pos security 2 unit, rumah dinas karyawan 26 unit, gudang pabrik 1 unit, gudang produksi 3 unit, gudang magazen 2 unit, gudang limbah 1 unit, gudang mesin hidran 1 unit, rumah genset 1 unit, gudang serat/gudang hasil 1 unit, Gudang mesin pompa air 1 unit, kolam hidran 1 unit, jembatan timbang 1 unit, lantai jemur 1 unit, bengkel dan garasi 1 unit.

Infrastruktur yang ada di PT Perkebunan Nusantara XIV Pabrik Kapas Jeneponto sudah mengalami kerusakan karena tidak adanya anggaran untuk pemeliharaan infrastruktur yang ada pada PT Perkebunan Nusantara XIV Pabrik Kapas jeneponto. Kebijakan privatisasi model joint operation pada PT Perkebunan Nusantara XIV Pabrik Kapas Jeneponto dilihat dari keuntungan yang dihasilkan dari kerjasama dengan pihak swasta (PT Supin Raya) tidak mencukupi untuk pemeliharaan infrastruktur milik PTPN XIV Pabrik Kapas Jeneponto.

\section{Hasil Kerjasama Joint Operation}

Dalam rangka Privatisai BUMN menimbulkan dampak Positif dan Negatif. Dampak positif dari privatisasi antara lain: (1) Meningkatnya tingkat profesionalitas kinerja dari sebuah perusahaan; (2) Meningkatkan Rating (peringkat/kelas) dari sebuah perusahaan; (3) Mengurangi defisit APBN; dan (4) Meningkatkan kepercayaan dari masyarakat.

Adapun dampak negatif dari privatisasi antara lain: (1) Pendapatan Negara menurun, karena sebagian sahamnya sudah dimiliki swasta; (2) Reputasi Negara dan pemimpinnya juga menurun karena dianggap tidak mampu mengelola sebuah perusahan milik Negara tanpa ada campur tangan swasta; (3) Negara akan mengalami kemunduran.

Namun yang berlaku pada PTPN XIV di Jeneponto cenderung merasakan dampak positifnya, dimana dapat meningkatkan nilai perusahaan. Hal ini sebagaimana dilihat dari hasil bermitra dengan perusahaan swasta dengan melakukan kerjasama operasional Uoint Operation) antara PT Perkebunan XIV Pabrik kapas Jeneponto dan PT Supin Raya. Dengan diadakannya kerjasama dengan PT Supin Raya, perusahaan yang terancam akan di non operasikan ini "terselamatkan" melalui sewa jasa pengolahan kapas berbiji milik PT Supin Raya yang dilakukan di Pabrik milik PT Perkebunan Nusantara XIV Pabrik Kapas Jeneponto.

Keuntungan yang didapatkan setiap tahunnya bervariasi tergantung dari jumlah kapas yang diterima untuk dikelola oleh perusahaan. Namun dengan kondisi perusahaan saat ini, apabila jumlah kapas yang akan dikelola kurang dari 100 ton, maka hasil dari pengelolaan tersebut masih merugikan perusahaan 
dikarenakan biaya produksi yang terus menerus naik di setiap tahunnya. Untuk mengantisipasi hal tersebut, perusahaan berupaya terus menerus menjalin komunikasi yang baik dengan pihak PT Supin Raya sehingga hal tersebut dapat terjadi. Hasilnya, setiap tahun sejak kerjasama ini mulai dijalin, jumlah kapas yang dikelola di pabrik perusahaan ini selalu melebihi 100 ton sehingga keuntungan tetap diperoleh oleh PT Perkebunan Nusantara XIV pabrik kapas Jeneponto dari hasil kerjasama ini dan euntungan yang sama dari hasil kerjasama ini juga diperoleh oleh PT Supin Raya.

Keuntungan yang didapat oleh PT Supin Raya berupa serat kapas yang telah siap untuk dijual. Kapas milik mereka yang telah diolah di pabrik milik PTPN XIV Pabrik Kapas Jeneponto telah dikemas dalam kemasan yang disediakan oleh PT Supin Raya. Selain menghasilkan serat kapas yang siap jual, hasil sampingan dari pengolahan berupa biji kapas dan kotoran kapas atau afpal tetap memiliki nilai jual. Biji kapas dikelola oleh PT Supin Raya untuk dijadikan bibit kapas dan dijual kembali kepada petani kapas sedangkan afpal atau kotoran kapas yang berupa serat-serat kapas yang pendek yang tidak bisa digunakan untuk membuat benang dijual kembali oleh PT Supin Raya kepada pembuat kasur.

\section{Faktor yang mempengaruhi terhadap Privatisasi pada PT. Perkebunan Nusantara XIV Pabrik Kapas Jeneponto dalam model Joint operation.}

\section{1) Faktor Keberhasilan Privatisasi Model Joint Operation}

a. Pengawasan yang Ketat

Pengawasan merupakan suatu usaha untuk mengawasi sesuatu sehingga dapat berjalan dengan lancar dan terkontrol sehingga dapat meminimalkan masalah yang mungkin muncul sesuai dengan konsep menurut Kadarman (2001: 159) pengawasan adalah suatu upaya yang sistematik untuk menetapkan kinerja standar pada perencanaan untuk merancang sistem umpan balik informasi, untuk membandingkan kinerja aktual dengan standar yang telah ditentukan, untuk menetapkan apakah telah terjadi suatu penyimpangan tersebut, serta untuk mengambil tindakan perbaikan yang diperlukan untuk menjamin bahwa semua sumber daya perusahaan telah digunakan seefektif dan seefisien mungkin guna mencapai tujuan perusahaan.

Dengan konsep pengawasan tersebut dalam hal ini, pengawasan atas kerjasama operasional (joint operation) antara PTPN XIV (Persero) Pabrik Kapas Jeneponto dan PT Supin Raya juga merupakan salah satu faktor yang diperlukan untuk keberhasilan jalinan kerjasama tersebut. Pengawasan sangat diperlukan sehingga jalannya kerjasama ini dapat di kontrol dan berjalan dengan lancar tanpa kendala yang berarti.

b. Banyaknya jumlah yang kapas masuk untuk diolah

Banyaknya jumlah kapas yang diterima untuk diolah sangat mempengaruhi keberhasilan dari kerjasama ini. Adanya standar minimal yang ditetapkan oleh perusahaan sangat cukup membantu untuk mengoptimalkan kinerja pengolahan. Semakin banyak kapas yang diolah di pabrik tersebut, maka semakin banyak kentungan yang akan diterima oleh pihak PTPN XIV pabrik kapas Jeneponto. Ini memungkinkan kelancaran proses kerjasama ini karena pihak PTPN XIV Pabrik Kapas jeneponto tetap bersedia untuk melanjutkan kerjasama dengan PT Supin Raya. Sehingga dapat dikatakan bahwa banyaknya jumlah kapas yang masuk merupakan salah satu faktor penentu berhasilnya kerjasama ini. 


\section{2) Faktor Kegagalan Model Joint Operation}

Privatisasi

Dalam berjalannya kerjasama operasional (Joint Operation) antara PT Perkebunan Nusantara XIV Pabrik Kapas jeneponto dan PT Supin Raya sejak 2008, tentunya memiliki berbagai kendala selama proses kerjasama ini terjalin. Namun, kendala-kendala tersebut dapat diselesaikan bersama dikarenakan komunikasi antara kedua perusahaan ini dapat terjalin dengan baik. Adapun kendala-kendala yang pernah terjadi yang sempat mengganggu jalannya kerjasama ini adalah:

a. Masalah dalam pembuatan surat perjanjian kerjasama

Masalah pernah terjadi antara pihak PT Perkebunan Nusantara XIV Pabrik Kapas Jeneponto dengan PT Supin Raya adalah pada tahun 2010 Biro Satuan Pengawasan Intern (SPI) melaksanakan pengawasan di Sub Unit Kapas Jeneponto. Dari hasil pemerikasaan tersebut, terdapat pengolahan kapas berbiji milik PT Supin Raya yang tidak sesuai dengan peraturan perusahaan.

Masalah ini terjadi akibat kurangnya pengawasan dari direktorat terkait yang menangani sub unit kapas Jeneponto. Akibatnya, sisa pembayaran biaya olah yang masih harus dibayar oleh PT Supin Raya Makassar sebesar Rp. 84. 513.825,- berpotensi terlambat dilunasi karena tidak adanya surat perjanjian kerjasama yang mengatur syarat-syarat pembayaran. Selain itu, pengeluaran biaya operasional dan sarana pendukung yang dilakukan oleh sub unit kapas Jeneponto tidak terkendali, karena kurangnya pengawasan. Karena itu, tidak adanya Surat perjanjian kerjasama atau kontrak dengan pihak mitra yang mengatur pasal-pasal hak dan kewajiban untuk menghindari hal-hal yang tidak diinginkan sangat diperlukan dimana PT Supin Raya telah memakai jasa pengolahan pabrik sejak tahun 2008 namun surat perjanjian kerjasama/kontrak kerjasama baru dibuat 3 tahun kemudian setelah adanya pemeriksaan Biro Satuan Intern (LPI).

b. Kesepakatan dalam menentukan harga sewa jasa produksi

Kendala yang muncul sebelum berjalannya proses pengolahan adalah tawar menawar dalam jumlah harga sewa jasa pengolahan. Untuk penentuan negosiasi harga tersebut, biasanya kenaikan harga dipengaruhi oleh kenaikan harga BBM. Kendala yang biasa dihadapi dalam proses negosiasi harga sewa jasa pengolahan adalah biaya sarana dan prasarana pengolahan yang naik setiap tahun seperti biaya gaji buruh penyortiran, harga pembelian kawat, karung, dan lain-lain. Namun, pihak PT Supin Raya menginginkan agar harga sewa disamakan dengan tahun lalu sehingga pihak PT Perkebunan Nusantara XIV (Persero) menolak keinginan tersebut. Hal ini menyebabkan proses pengolahan menjadi terhambat. Namun, hal ini dapat diselesaikan setiap tahunnya dengan komunikasi yang baik diantara keduanya.

c. Keterlambatan pembayaran sewa jasa pengolahan

Masalah yang biasa terjadi yang diakibatkan oleh keterlambatan pembayaran ini adalah terlambat waktu untuk pembayaran upah buruh sortir. Selain itu, keterlambatan pembayaran ini tentunya dapat mengganggu kelancaran kerjasama ini dikarenakan dapat menimbulkan rasa ketidak percayaan dari pihak PTPN XIV (Persero) kepada pihak PT Supin Raya. Sehingga keterlambatan pembayaran ini dapat menjadi kendala yang cukup serius bagi kelangsungan kerjasama ini.

d. Kendala di lapangan pada saat penerimaan kapas dari mitra petani milik PT Supin Raya

Masalah ini hampir setiap tahun dialami oleh pihak PT Supin Raya dimana 
pada saat pembelian kapas dengan mitra petani kapas. Jumlah kapas yang diterima oleh pihak PT Supin Raya dari para mitra petani kadang tidak memenuhi target yang diinginkan. Tentu saja hal ini mempengaruhi jumlah kapas yang akan diterima oleh pihak PT Perkebunan Nusantara XIV Pabrik Kapas jeneponto untuk dikelola di pabriknya.

Oleh karena itu, masalah yang muncul di lapangan pada saat kurangnya pasokan kapas dari mitra petani akan menjadi salah satu kendala dari kelancaran kerjasama ini dikarenakan jumlah kapas yang akan diterima untuk dikelola di pabrik milik PT Perkebunan Nusantara XIV Pabrik Kapas jeneponto akan kurang dari target jumlah minimal kapas berbiji yang akan dikelola.

e. Keterlambatan sarana dan prasarana produksi

Keterlambatan sarana dan prasaran produksi dapat mengganggu berjalannya proses pengolahan kapas berbiji milik PT Supin Raya. Ketepatan waktu dalam pengecekan mesin pabrik, penyediaan sarana dan prasarana pengolahan seperti penyediaan buruh penyortiran, kawat, karung, dan lain-lain sangat diperlukan agar proses pengolahan dapat selesai sesuai dengan target waktu yang telah disepakati bersama.

\section{E. PENUTUP}

Berdasarkan hasil penelitian yang dilakukan maka penulis menyimpulkan sebagai berikut: (1) Kondisi PTPN XIV (Persero) saat berdirinya kurang sehat, yang di tunjukkan dengan kinerja perusahaan. Perusahaan meyakini bahwa peluang terbesar untuk tumbuh dan berkembang adalah dengan melakukan kerjasama dengan mitra strategis. Kemudian dalam pengelolaannya di terapkanlah Privatisasi dalam bentuk Joint Operation pada PT. Perkebunan Nusantara XIV Pabrik Kapas Jeneponto saat ini dengan PT Supin Raya; (2) Kurangnya pengawasan dalam proses kerjasama dimana tidak adanya surat perjanjian kerjasama secara tertulis.

Faktor keberhasilan Privatisasi dalam Model Joint Operation dimana adanya pengawasan dalam proses kerjasama, banyaknya jumlah pasokan kapas yang akan diolah, sedangkan faktor kegagalan Privatisasi Model Joint Operation adanya masalah dalam pembuatan surat perjanjian, kesepakatan dalam menentukan sewa jasa produksi, keterlambatan pembayaran sewa jasa pengolahan, kendala dilapangan pada saat penerimaan kapas dari mitra petani milik PT Supin Raya, keterlambatan sarana dan prasarana produksi.

Dengan memperhatikan kesimpulan di atas maka penulis merasa perlu memberikan beberapa saran sebagai berikut: (1) Diperlukan adanya surat perjanjian secara tertulis sebelum melakukan kerjasama, agar tidak terjadi hal-hal yang dapat merugikan dari proses kerjasama; (2) Unit usaha yang mepunyai skala usaha kecil tetapi mempunyai prospek yang baik diberikan kewenangan untuk menjadi anak perusahaan sehingga mempunyai keleluasaan berusaha dengan memanfaatkan sumber daya luar (out sourching) untuk mengelola uasahanya tanpa membebani cash flow perusahaan (perusahaan holding); (3) Unit usaha yang tidak mempunyai prospek berdasarkan perekembangan kondisi dapat ditutup, dijual atau diubah menjadi usaha lain yang mempunyai prospek; dan (4) Merekturisasi proyek atau program pengembangan yang sudah tidak sesuai dengan perkembangan perusahaan.

\section{DAFTAR PUSTAKA}

Asropi. 2008. Menilik Kinerja Privatisasi: Perbandingan Malaysia dan Indonesia. Jurnal Administrator Borneo; Volume 4; Nomor 2; halaman 1269-1287. 
Bastian, Indra. Perlunya Badan Usaha Milik Negara (BUMN) di Privatisasi. Jurnal Universitas Sumatera Utara. Vol 3 No. 2,

Creswell, John W. 2010. Research Design, Pendekatan Kualitatif, Kuantitatif, dan Mixed. Yogyakarta: Pustaka Pelajar.

Habibullah. 2009. Kebijakan Privatisasi BUMN: Relasi State, Market, dan Civil Society. Malang: Avverroes Press.

Haggara, Arie. 2012. Dampak Privatisasi Badan Usaha Milik Negara bagi perekonomian dan kesejahteraan rakyat Indonesia, http://ariehukum.blogspot.com/20 12/12/privatisasi-bumn.html (diakses pada tanggal 15 September 2013 ).

Hakim, Lukman. 2010. Pemberdayaan Masyarakat: Sketsa Teori dan Pendekatan. Makassar: Berkah Utami.

Hidayat, Benny. 2012. Privatisasi kebaikan dan keburukannya, Bantaeng pada 8 Januari 2012 http://benny77jeka. blogspot.com/2012/01/privatisasikebaikan-dan keburukannya.html (diakses pada tanggal 21 Agustus 2013)

Istianto, Bambang. 2011. Privatisasi: Dalam Model Public Private Parthnership. Jakarta: Mitra Wacana Media.

Mustari, Nuryanti. 2013. Implementasi Kebijakan Publik: Pemahaman Teoritis Empiris. Makassar: Membumi Publishing.
Prasetio, Bimo. 2013. Kerjasama Usaha dalam bentuk KSO, Jakarta 01 juli 2013

http://strategihukum.net/kerjasam a-usaha-dalam-bentuk-kso-2 (di akses pada tanggal 3 januari 2014)

Sugiyono.2013. Metode Penelitian Pendidikan. Bandung: Alfabeta.

\section{Dokumen}

Anggaran dasar PT. Perkebunan XIV (Persero) pasal 3 ayat 1 .

UU No 19 Tahun 2003 tentang BUMN.

Peraturan Pemerintah Nomor 59 Tahun 2009 Tentang Perubahan

Peraturan Pemerintah Nomor 33 Tahun 2005 Tentang tata cara Privatisasi Persero. 